\title{
Ancylotherium pentelicum (Mammalia, Chalicotheriidae) from the late Miocene of Kerassia (Greece) and remarks on its intraspecific variability
}

\author{
Panagiotis Kampouridis ${ }^{1}$ (D) - Socrates J. Roussiakis ${ }^{2} \cdot$ loannis X. Giaourtsakis ${ }^{3} \cdot$ Nikolaos Kargopoulos $^{1}$ (D) \\ Georgia Svorligkou ${ }^{2}$ (D) $\cdot$ Georgios E. Theodorou ${ }^{2}$
}

Received: 4 December 2020 / Revised: 19 February 2021 / Accepted: 20 April 2021 / Published online: 13 July 2021

(C) The Author(s) 2021

\begin{abstract}
The first detailed description of Ancylotherium pentelicum (Gaudry and Lartet, 1856) from the late Miocene (Turolian) of Kerassia (Greece) is provided based on three metapodial elements. Potential intraspecific variability of this species in the Eastern Mediterranean has been previously discussed, but no decisive conclusions could be drawn. The present comparison of metapodial elements of A. pentelicum from Kerassia, Pikermi, Samos (Greece), Pinaryaka, Salihpaşalar (Turkey), Kiro Kuchuk (North Macedonia), and Hadjidimovo (Bulgaria) provides evidence for the existence of notable intraspecific variation in both the morphology and especially the size of the species. The morphological differences in the shape and occurrence of some metapodial articular facets are probably associated with the anticipated individual variability and not with sexual dimorphism. On the other hand, the notable metrical variability observed among metapodials of A. pentelicum may be indicative of sexual dimorphism, as has been previously documented in other chalicotheriids.
\end{abstract}

Keywords Chalicotheres $\cdot$ Intraspecific variability $\cdot$ Postcranial $\cdot$ Turolian $\cdot$ Eastern Mediterranean

\section{Introduction}

Members of the family Chalicotheriidae were peculiar clawed perissodactyls that went extinct in the Pleistocene (Coombs and Cote 2010). They are an unusual group, unlike any living perissodactyl, and lack any true modern analogue (Coombs 1983). Originally, postcranial remains of these animals were referred to giant pangolins (Cuvier 1823), because of their large claws. The existence of claws instead of hooves is indeed a unique feature of the family Chalicotheriidae within the Perissodactyla. The same feature also led to their association

Panagiotis Kampouridis

pkampouridis94@gmail.com

1 Department of Geoscience, Eberhard Karls University of Tübingen, Sigwartstr. 10, 72074 Tübingen, Germany

2 Department of Historical Geology and Palaeontology, Faculty of Geology and Geoenvironment, National and Kapodistrian University of Athens, Panepistimiopolis, 15784 Athens, Greece

3 Department of Earth and Environmental Sciences, Palaeontology and Geobiology, Ludwig-Maximilians-Universität München, Richard-Wagner-Str. 10, 80333 München, Germany with sloths (Lartet 1837). Due to their unusual limb proportions, some chalicotheres (Chalicotheriinae) have been compared to gorillas, and knuckle-walking locomotion has been proposed (Zapfe 1979), whereas other representatives (Schizotheriinae) have proportions more like modern okapis (Coombs 1983).

Schulz et al. (2007) studied the micro- and mesowear patterns of the dentition of European Miocene Chalicotheriidae and proposed that their diet included a substantial amount of bark and twigs. Subsequent studies further supported this ecological niche for the chalicotheres (Schulz and Fahlke 2009; Semprebon et al. 2011). As far as Ancylotherium pentelicum (Gaudry and Lartet, 1856) is concerned, Semprebon et al. (2011) studied several chalicotheres, including a small sample (five specimens, three of which belonged to juvenile individuals) of A. pentelicum, inferring a diet composed of leaves, twigs, and bark, despite the fact that it features the most highcrowned dentition among all chalicotheres (Semprebon et al. 2011).

Representatives of the family Chalicotheriidae are rare but typical faunal elements of the late Miocene sub-Paratethyan bioprovince (sensu Bernor 1983) or Greco-Iranian (BalkanIranian) bioprovince (sensu de Bonis et al. 1992). During the 
Turolian, four species of Chalicotheriidae have been reported in the Balkan and Anatolian Peninsulas: the three chalicotheriines Chalicotherium goldfussi Kaup, 1833, Kalimantsia bulgarica Geraads et al., 2001 and Anisodon macedonicus (de Bonis et al., 1995), and the schizotheriine A. pentelicum (Geraads et al., 2001; Giaourtsakis and Koufos, 2009; Koufos, 2012).

The earliest potential occurrence of Ancylotherium has been reported from the French late middle Miocene (MN 7/8) locality La Grive St.-Alban (Fahlke and Coombs 2009, p. 87-88; Coombs 2009, p. 122). The chalicothere material from La Grive has been known for well over a century and has been referred to various taxa over time. Von Koenigswald (1932) included teeth of the schizotheriine chalicothere from La Grive within Metaschizotherium fraasi Von Koenigswald, 1932. Later, Mein and Ginsburg (2002) erected the new species Phyllotillon grivensis Mein and Ginsburg, 2002 for the material from La Grive. Fahlke and Coombs (2009) and Coombs (2009) discussed the taxonomy of the schizotheriine chalicothere from La Grive and suggested that it might represent an early Ancylotherium species. During the Vallesian, the species Ancylotherium hellenicum Koufos 2012 from Pentalophos 1 represents the oldest occurrence of the genus in the Eastern Mediterranean (Koufos 2012). During the Turolian, the dominant chalicothere of the Eastern Mediterranean region is A. pentelicum (Giaourtsakis and Koufos 2009; Koufos 2012). Its biogeographical distribution ranged at least from the Balkan peninsula to Iran (Fig. 1), covering the entire sub-Paratethyan bioprovince (Koufos and Kostopoulos 2016). Material associated with the genus Ancylotherium has been also reported from several late Miocene localities in the Iberian Peninsula, including the Turolian site Concud and the Vallesian sites Los Valles de Fuentidueña and Nombrevilla in Spain (Alberdi et al. 1981). Coombs (2009) proposed the assignment of the material from Los Valles de Fuentidueña to Ancylotherium sp., whereas Koufos (2012) discussed a possible assignment of this material to Ancylotherium hellenicum. However, the scarcity of the Iberian material does not currently suffice for any definite conclusion (Giaourtsakis and Koufos 2009).

\section{Material and methods}

Kerassia is a late Miocene (Turolian) fossiliferous locality, situated in the northern part of Euboea Island, Greece (Fig. 1). The initial excavation was conducted in 1982 by $\mathrm{H}$. de Bruijn and A. van der Meulen (University of Utrecht) in collaboration with C. Doukas (National and Kapodistrian University of Athens; NKUA). Starting in 1992, G. Theodorou (NKUA) started extensive excavations in the area, which led to the description of a very diverse fauna (Roussiakis and Theodorou 2003; Theodorou et al. 2003;
Giaourtsakis et al. 2006; Athanassiou et al. 2014; Kampouridis and Dimakopoulos 2018; Kampouridis et al. 2019, 2020a; Roussiakis et al. 2021). Overall, seven fossiliferous sites have been uncovered, which can be correlated with two distinct stratigraphical horizons (Iliopoulos 2003; Kampouridis et al. 2019). The sites Kerassia 2 (K2), Kerassia 3 (K3), Kerassia 4 (K4), and Kerassia 5 (K5) belong to the lower horizon, whereas Kerassia 1 (K1) and Kerassia 6 (K6) belong to the upper horizon. The associated fauna points to a middle Turolian age (MN12), but an early Turolian age (MN11), cannot be presently excluded (Theodorou et al. 2003; Kampouridis et al. 2019). Furthermore, the available data do not permit a biochronological differentiation between the two fossiliferous horizons.

The studied material consists of a right Mt-II (K4/119/7) from the lower fossiliferous horizon of Kerassia (site K4), as well as a left Mc-III (K1/80) and a left Mt-III (K1/171), from the upper horizon (site K1). The material is housed in the collections of the Museum of Palaeontology and Geology of the NKUA (AMPG). The aim of the present contribution is the detailed study of the chalicotheriid material from Kerassia and its morphological and morphometrical comparison with respective material from other localities of the Eastern Mediterranean region. Furthermore, a discussion of the intraspecific variability of A. pentelicum is provided. Previously, the occurrence of Ancylotherium sp. in Kerassia was briefly mentioned in a preliminary overview on the herbivores of the locality (Theodorou et al. 2003). A preliminary version of this study was presented at the 2nd Palaeontological Virtual Congress (Kampouridis et al. 2020b).

The measurements follow Roussiakis and Theodorou (2001); they were taken with a digital caliper with an error of 0.01 and then rounded to the first decimal.

Measurement abbreviations: 1, Lmax; 2, DTprox; 3, DAPprox; 4, DTdia; 5, DAPdia; 6, DTdistmax; 7, DTdist; 8, DAPdist.

Institutional abbreviations: AMPG: Athens Museum of Palaeontology and Geology, National and Kapodistrian University of Athens; MMNH: North Macedonian Museum of Natural History, Skopje; NHML: Natural History Museum, London.

\section{Systematic palaeontology}

Class Mammalia Linnaeus, 1758

Order Perissodactyla Owen, 1848

Family Chalicotheriidae Gill, 1872

Subfamily Schizotheriinae Holland and Peterson, 1914

Genus Ancylotherium Gaudry, 1862

Ancylotherium pentelicum (Gaudry and Lartet, 1856) 


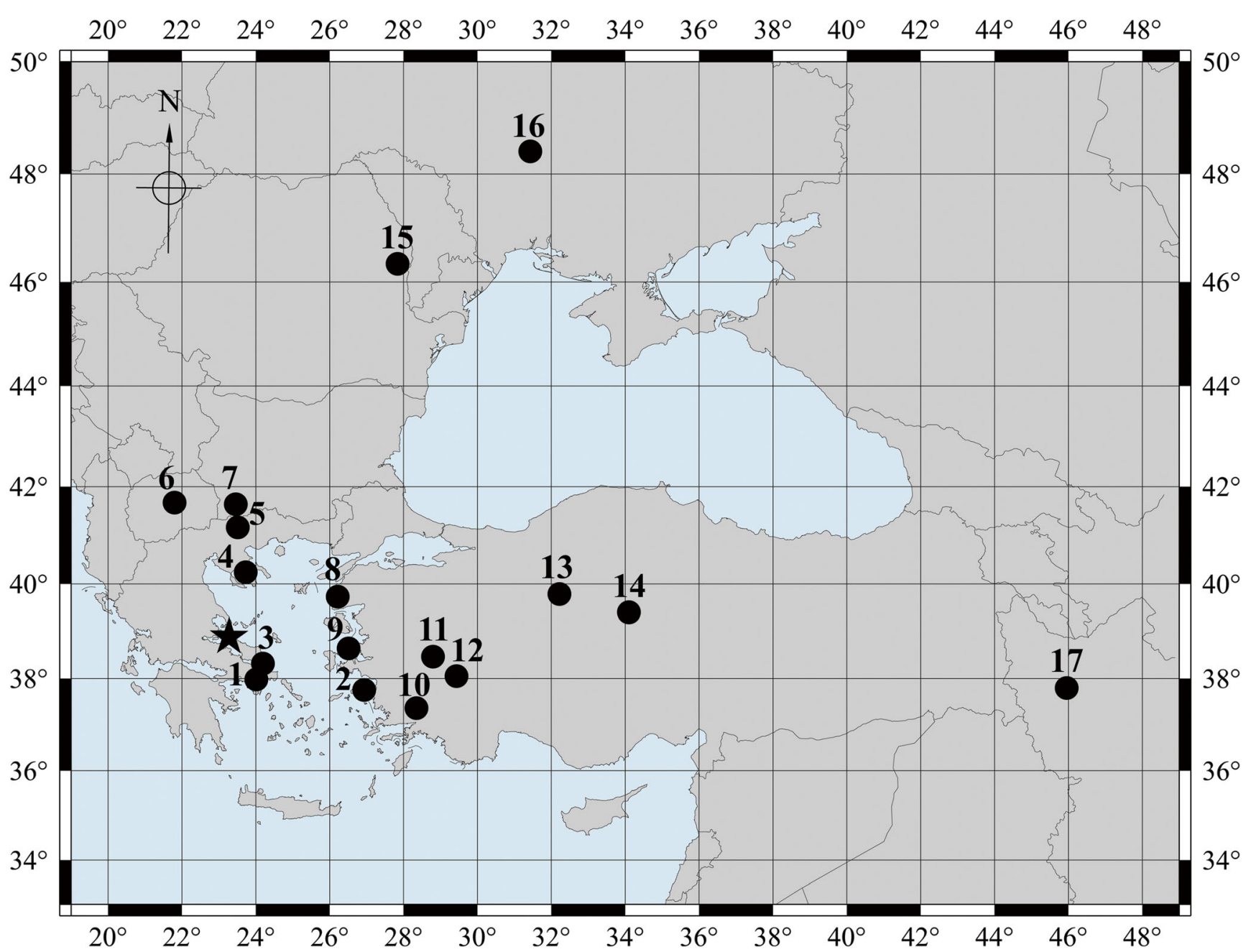

Fig. 1 Map with the occurrences of Ancylotherium pentelicum (Gaudry and Lartet, 1856) in the sub-Paratethyan (Balkan-Iranian) bioprovince. The black star represents Kerassia. The black dots represent: 1 Pikermi (Roussiakis and Theodorou 2001); 2 Samos (Giaourstakis and Koufos 2009); 3 Halmyropotamos (Roussiakis and Theodorou 2001); 4 Nikiti 2 (Koufos and Kostopoulos 2006); 5 Thermopigi (Geraads et al. 2007) (Greece); 6 North Macedonian localities (Karaslari, Kiro Kuchuk and Prevalets) (Spassov et al. 2018); 7 Bulgarian localities (Hadjidimovo 1,
Hadjidimovo 2, Kalimantsi, Gorna Sushitsa 7 and Strumyani) (Geraads et al. 2001, 2006; Spassov et al. 2019); 8 Gülpinar (Saraç and Sen 2005); 9 Karaburun (Kaya et al. 2005); 10 Salihpaşalar (Saraç and Sen 2005); 11 Kemiklitepe (Sen 1994); 12 Mahmutgazi (Geraads 2017); 13 Pinaryaka (Saraç and Sen 2005); 14 Akkaşdağ 1 (Saraç and Sen 2005) (Turkey); 15 Pogana (Romania); 16 Novoukrainka (Ukraine); and 17 Maragha (Iran) (Giaourtsakis and Koufos 2009, fig. 1). The map was created using Generic Mapping Tools (Wessel et al. 2013)
Localities: Kerassia 1 (K1); Kerassia 4 (K4)

Material: left Mc-III (K1/80), right Mt-II (K4/119/7) and left Mt-III (K1/171)

Age: Late Miocene (Turolian; MN11?-MN12)

\section{Description}

$\mathrm{K} 1 / 80$ is a moderately well-preserved right Mc-III (Figs. $2 \mathrm{a}-\mathrm{d}$ and $3 \mathrm{a}, 3 \mathrm{~d}$ ), missing the distal articular head; only a small remnant of the epiphysis is preserved. In proximal view, three articular facets for the distal carpal bones can be distinguished. Medially, the articular facet for the Mc-II is concave and has a rectangular outline, being oblique towards its medial side. In the middle of the proximal surface is a rectangular and slightly concave articular facet for the magnum. Laterally, an articular facet for the unciform protrudes slightly. The anterior parts of the articular facets for the unciform and Mc-IV are damaged. In lateral view, beneath the thin articular stripe for the unciform, an articular facet for the Mc-IV is placed. The two facets are connected throughout their longest axis. Their exact morphology cannot be assessed due to their state of preservation. The shaft of the Mc-III is anteroposteriorly flattened, featuring a concave anterior side and an almost straight posterior aspect. The bone is considerably longer and 

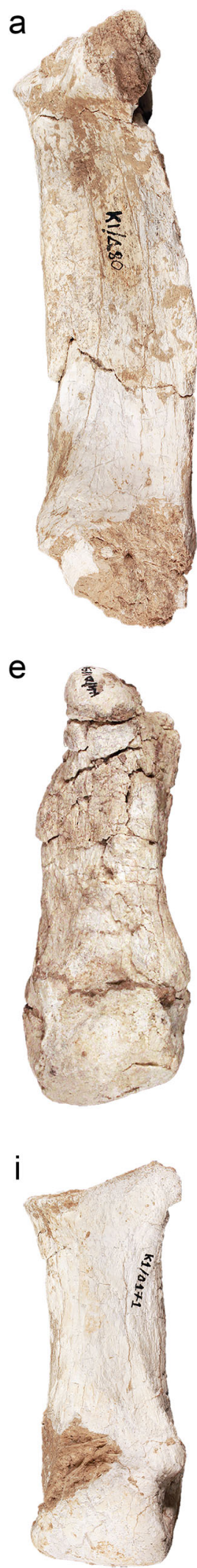

Fig. 2 Material of Ancylotherium pentelicum (Gaudry and Lartet, 1856) from Kerassia (Greece): a-d left Mc-III from Kerassia 1 (K1/80) in a anterior, $\mathbf{b}$ posterior, $\mathbf{c}$ medial, and $\mathbf{d}$ lateral view; $\mathbf{e}-\mathbf{h}$ right $\mathrm{Mt}-\mathrm{II}$ from
C

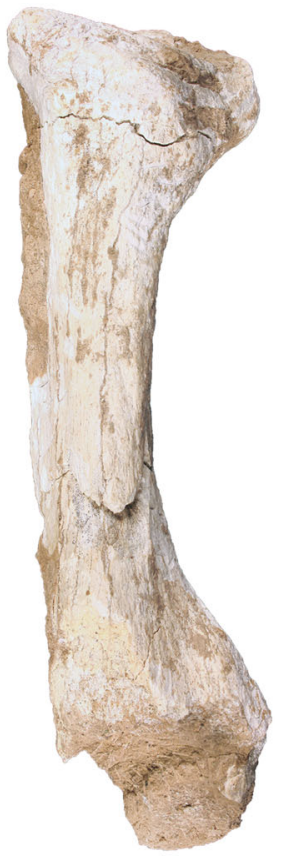

g

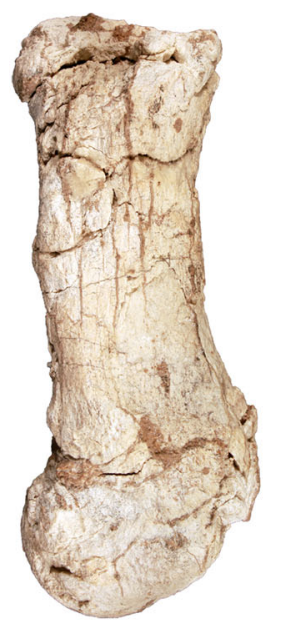

$\mathrm{k}$

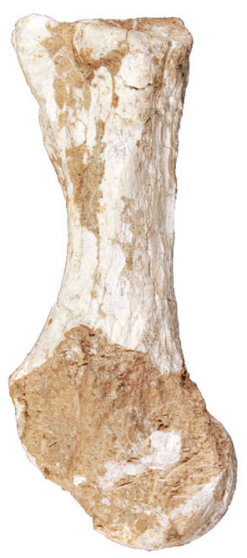

d

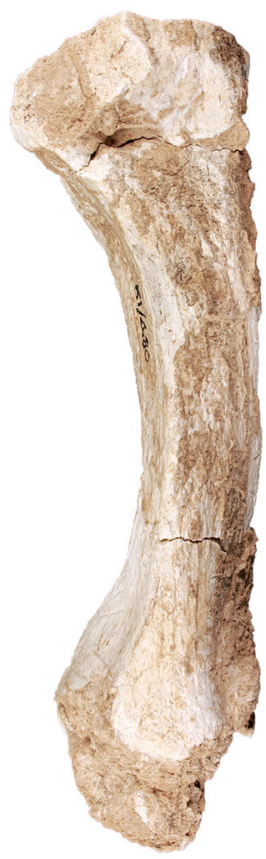

h

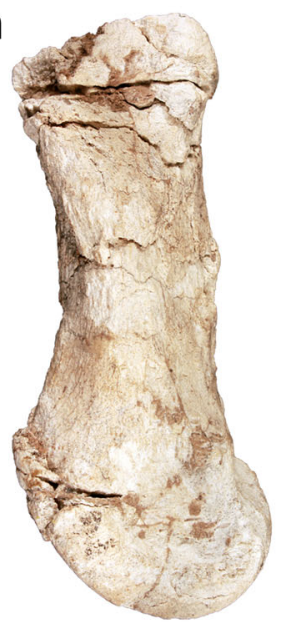

I

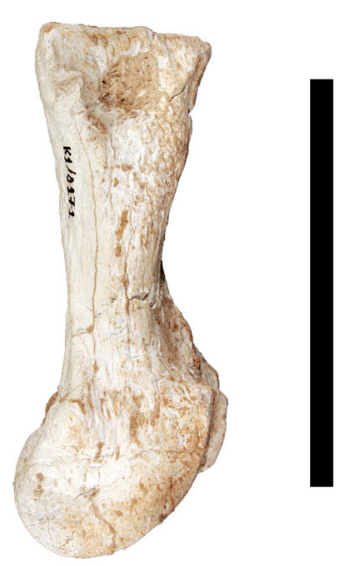

Kerassia 4 (K4/119/7) in e anterior, f posterior, $\mathbf{g}$ medial, and $\mathbf{h}$ lateral view; and $\mathbf{i}-\mathbf{l}$ left Mt-III from Kerassia $1(\mathrm{~K} 1 / 171)$ in $\mathbf{i}$ anterior, $\mathbf{j}$ posterior, $\mathbf{k}$ medial, and $\mathbf{I}$ lateral view. The scale bar is $10 \mathrm{~cm}$ 

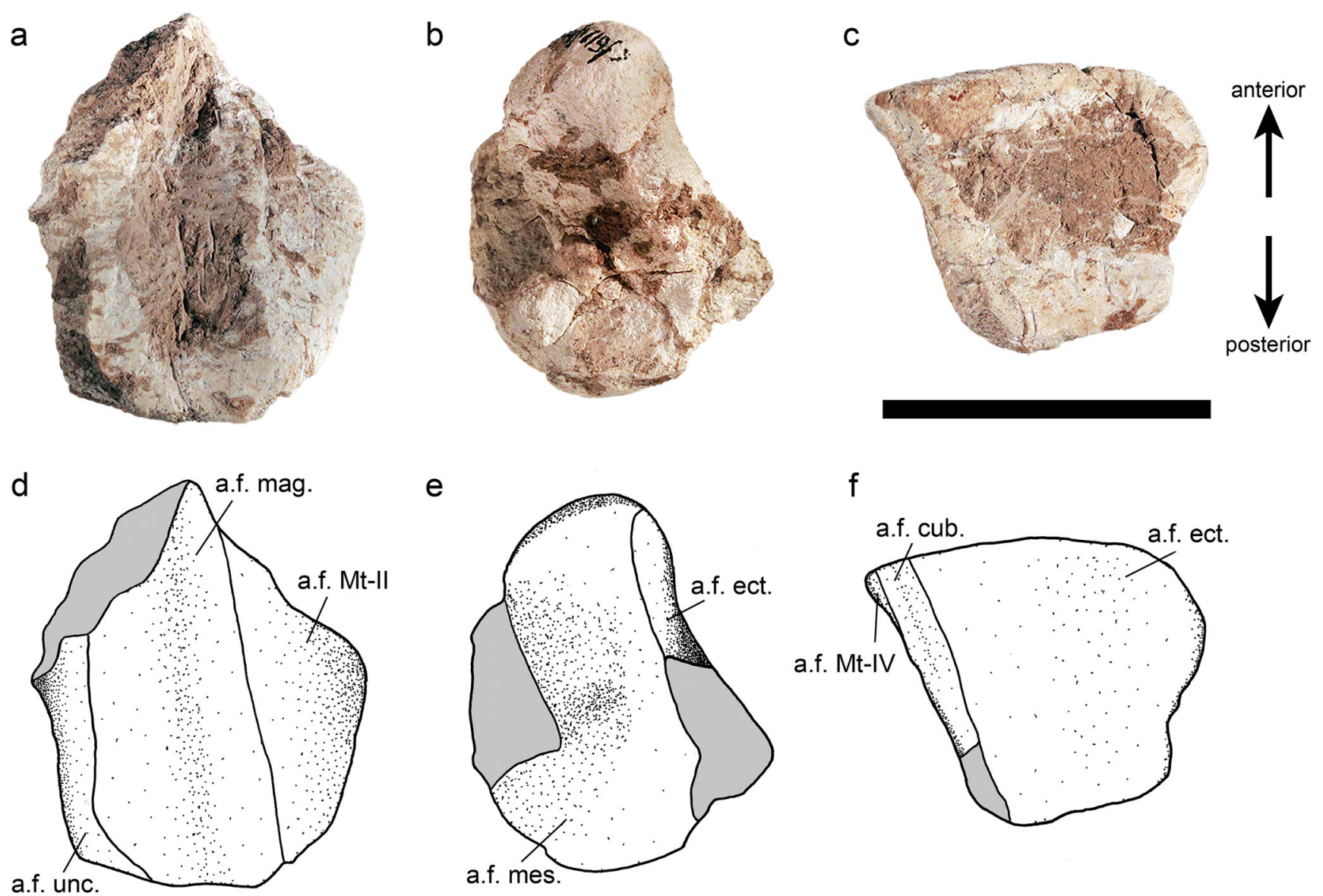

Fig. 3 Material of Ancylotherium pentelicum (Gaudry and Lartet, 1856) from Kerassia (Greece): a left Mc-III from Kerassia 1 (K1/80), b right MtII from Kerassia 4 (K4/119/7), and c left Mt-III from Kerassia 1 (K1/171) in proximal view, and $\mathbf{d}-\mathbf{f}$ drawings of the respective metapodium, grey areas represent damaged parts of the bones. Abbreviations: a.f. cub.

articular facet for the cuboid; $a$.f. ect. articular facet for the ectocuneiform; a.f. mag. articular facet for the magnum; a.f. mes. articular facet for the mesocuneiform; $a . f$. Mt-II articular facet for the Mt-II; a.f. Mt-IV articular facet for the Mt-IV; and a.f. unc. articular facet for the unciform. The scale bar is $5 \mathrm{~cm}$

relatively slenderer with respect to the shaft of the two metatarsal specimens (Fig. 2).

$\mathrm{K} 4 / 119 / 7$ is a moderately well-preserved right Mt-II (Figs. 2e-h and 3b, 3e); the proximal and distal parts of the bone are partially damaged. In proximal view, the articular facet for the mesocuneiform is damaged in its medial and posterolateral aspects. The outline of this articular facet seems to have been semi-ovate. In medial view, the surface of the bone is exfoliated, and the morphology cannot be assessed. In proximal view, the articular facet for the ectocuneiform is obliquely placed on the lateral side of the bone. In proximolateral view, the articular facet for the ectocuneiform is shaped as a gently concave articular stripe, but it is partially broken in its posterior part. Distally to the ectocuneiform facet, an articular facet for the Mt-III seems to have been present, but its size and shape cannot be accurately evaluated due to the poor state of preservation. The shaft of the bone features a sub-triangular cross section; its lateral aspect is considerably thicker than the medial one. The distal epiphysis is still attached to the specimen; however, there is a thin and partially continuous crack, which is partly filled with sediment that seems to slightly separate the distal epiphysis from the shaft. This could indicate a sub-adult age for the specimen; however, as the bone is quite fragmented and features numerous cracks, it is not possible to attribute with absolute certainty this specific crack to the suture which connects the distal epiphysis with the shaft. There is a strong possibility that the specimen belongs to a sub-adult individual, which was almost full-grown, and thereby, the dimensions of the bone would not have changed significantly during maturation. In anterior view, the proximal border of the articular surface for the proximal phalanx is convex. In posterior view, the medial and lateral articular facets for the respective sesamoid bones are poorly preserved; they seem to have been separated by a blunt sagittal keel. In medial view, the depression for the attachment of the medial collateral sesamoidean ligament is relatively small and very shallow; in lateral view, the corresponding depression for 
the lateral collateral sesamoidean ligament is larger and deeper. The bilateral protuberances of the distal end, which serve as attachment sites for the collateral ligaments of the fetlock joint, are weakly expressed.

$\mathrm{K} 1 / 171$ is a fairly complete left Mt-III (Figs. $2 \mathrm{i}-1$ and 3c, $3 \mathrm{f}$ ), with a slightly damaged distal epiphysis. In medial view, the articular facet for the Mt-II is only partially preserved. In proximal view, the articular facet for the ectocuneiform is well-preserved and features a sub-trapezoidal outline. A narrow but well-defined articular stripe, located in between the articular facets for the ectocuneiform and the Mt-IV, represents a small dedicated articular facet for the cuboid. In lateral view, the articular facet for the Mt-IV is divided into two parts. The anterior part is partially broken, but it seems to have been sub-trapezoidal, whereas the posterior one is also somewhat damaged, but it features a sub-triangular outline. These two facets for the Mt-IV are connected by a narrow articular stripe. The shaft is anteroposteriorly somewhat flattened and has an almost elliptic shape. On the distal half of the bone, the articular head for the proximal phalanx is notably prominent with respect to the shaft. In posterior view, the medial and lateral articular facets for the respective sesamoid bones are separated by a low and blunt sagittal keel. The medial aspect of the distal end is damaged. In lateral view, the depression for the attachment of the lateral collateral sesamoidean ligament is deep. The lateral protuberance for the attachment of the corresponding collateral ligaments of the fetlock joint is bulbous and pronounced.

\section{Remarks}

The studied material (Figs. 2 and 3 ) belongs to a schizotheriine chalicotheriid, as it exhibits several features that distinguish it from Turolian chalicotheriines. The metatarsals of chalicotheriines are much shorter and more robustly built with a stronger sagittal keel (Zapfe 1979), in contrast to the more elongated and slenderer metatarsals from Kerassia, which clearly resemble those of A. pentelicum (Gaudry 1862-67; Roussiakis and Theodorou 2001; Saraç et al. 2002; Giaourtsakis and Koufos 2009). The Mc-III from Kerassia has a characteristically flattened, strongly curved, and anteriorly concave shaft, typical of A. pentelicum (Schaub 1943; Roussiakis and Theodorou 2001; Coombs 2009). The Turolian age of the Kerassia fauna is in accordance with the known temporal and spatial range of A. pentelicum, which is the only schizotheriine that has been reported from the Turolian of the Eastern Mediterranean (Koufos 2012).

The material from Kerassia is morphologically similar to respective material from Pikermi, the type locality of A. pentelicum, but demonstrates some interesting variation regarding the size of the bones. Concerning K1/80, its measurable dimensions (Table 1) are similar to that of PG 59/519, a juvenile Mc-III from Pikermi (Roussiakis and Theodorou
2001), and significantly smaller than the adult specimens from the same locality. Specimen K1/171 belongs definitely to an adult individual, but it is smaller with respect to the known Mt-III specimens of A. pentelicum (Table 3); in particular, its length is smaller than any Mt-III assigned to this species thus far (Fig. 4). Both K1/80 and K1/171 come from the site K1.

In contrast to the Kerassia 1 specimens, specimen K4/119/ 7 , which originates from the lower horizon of the locality, is, despite its potential sub-adult age, larger than any described Mt-II of this species from the Eastern Mediterranean. However, it has to be noted that only very few other specimens of Mt-II are known (Table 2). More specifically, only eight specimens, that belong to adult individuals, including $\mathrm{K} 4 / 119 / 7$, have been mentioned in the literature (Zapfe 1979; Sen 1994; Roussiakis and Theodorou 2001; Saraç et al. 2002; Spassov et al. 2018). From Pikermi, the type locality of A. pentelicum, only three Mt-IIs are known, one of which belongs to a juvenile individual (Roussiakis and Theodorou 2001). All available specimens are smaller than the specimen from Kerassia, especially in their length (Fig. 4).

The Mt-III from Kerassia (K1/171) can be easily distinguished from other schizotheriines, such as Moropus and Metaschizotherium (Coombs 1978, 2009; Fahlke and Coombs 2009), but it is morphologically almost indistinguishable from the Mt-IIIs of A. pentelicum. The presence of an articular facet for the cuboid, placed between the articular facet for the ectocuneiform and the articular facets for the Mt-IV, is a variable feature within the species. Giaourtsakis and Koufos (2009) mentioned its absence in two specimens from Samos and one specimen from Pikermi, while they reported its presence in another Mt-III from Pikermi. In the MtII, the outline of the articular facet for the mesocuneiform seems to be a variable feature within A. pentelicum. In two specimens from Pinaryaka (Turkey), one features a triangular outline, whereas the other one a circular outline (Saraç et al. 2002). In K4/119/7, this articular facet is somewhat damaged, but was probably semi-ovate.

\section{Discussion}

The existence of morphological and morphometrical variability within A. pentelicum has been frequently discussed (Saraç et al. 2002; Geraads et al. 2006; Giaourtsakis and Koufos 2009). Geraads et al. (2007) described a complete skull of A. pentelicum from the late Miocene of Thermopigi (Greece), which exhibits a characteristic inflation of the frontal bones. Another skull from Karaslari exhibits a similarly developed inflation of the frontal bones (Spassov et al. 2018). A similar cranial feature has been also observed in the schizotheriine Tylocephalonyx (Coombs 1979; Munthe and Coombs 1979). Unfortunately, attributing the skulls from Thermopigi and Karaslari to male individuals is not 
Table 1 Measurements (in mm) of the Mc-III of Ancylotherium pentelicum (Gaudry and Lartet, 1856). Measurement abbreviations: 1, Lmax; 2, DTprox; 3, DAPprox; 4, DTdia; 5, DAPdia; 6, DTdistmax; 7, DTdist; 8, DAPdist

\begin{tabular}{|c|c|c|c|c|c|c|c|c|c|c|}
\hline Specimen No. & Reference & Locality & 1 & 2 & 3 & 4 & 5 & 6 & 7 & 8 \\
\hline $\mathrm{K} 1 / 80$ & This study & Kerassia 1 & $>185$ & $>48$ & 63 & - & 50.4 & - & - & - \\
\hline PG 95/519 (juvenile) & Roussiakis and Theodorou 2001 & Pikermi & - & 48.3 & 62.2 & - & - & - & - & - \\
\hline PG 95/511 & Roussiakis and Theodorou 2001 & Pikermi & 296.4 & 57 & 74 & 69.4 & - & 83 & 80.5 & 83 \\
\hline PG 95/508 & Roussiakis and Theodorou 2001 & Pikermi & 294.5 & 54.8 & 82.2 & 64.3 & - & - & - & $\sim 96.5$ \\
\hline PG 95/507 & Roussiakis and Theodorou 2001 & Pikermi & 279.5 & $\sim 52$ & 84.5 & - & - & $\sim 84.2$ & 75.4 & 77.6 \\
\hline PG 95/518 & Roussiakis and Theodorou 2001 & Pikermi & - & - & - & - & - & 83.2 & 79.2 & 88.1 \\
\hline PG 95/550 & Roussiakis and Theodorou 2001 & Pikermi & - & $\sim 59$ & 76.5 & - & - & - & - & - \\
\hline AMNH32504 & Coombs 1978 & Pikermi & 279 & - & - & - & - & - & - & - \\
\hline- & Schaub 1943 & Samos & 276 & 59 & 72 & 59 & - & 74 & 65 & 83 \\
\hline- & Schaub 1943 & Samos & 294 & - & - & 61 & - & 88 & $\sim 61$ & 74 \\
\hline- & Schaub 1943 & Veles & - & 63 & - & - & - & - & - & - \\
\hline- & Schaub 1943 & Veles & - & - & - & - & - & 78 & 64 & 80 \\
\hline HD-528 & Geraads et al. 2006 & Hadjidimovo & 245 & - & 67 & 48.5 & - & - & 63 & 66.5 \\
\hline AAP-47 & Sarac et al. 2002 & Pinaryaka & 288 & 66 & 78 & 61 & - & 75 & - & 84 \\
\hline AAP-50 & Sarac et al. 2002 & Pinaryaka & - & 64 & 76 & 61 & - & - & - & - \\
\hline
\end{tabular}

conclusive at the moment (Geraads et al. 2007), since a female skull of Ancylotherium, presumably lacking this feature, is not known.

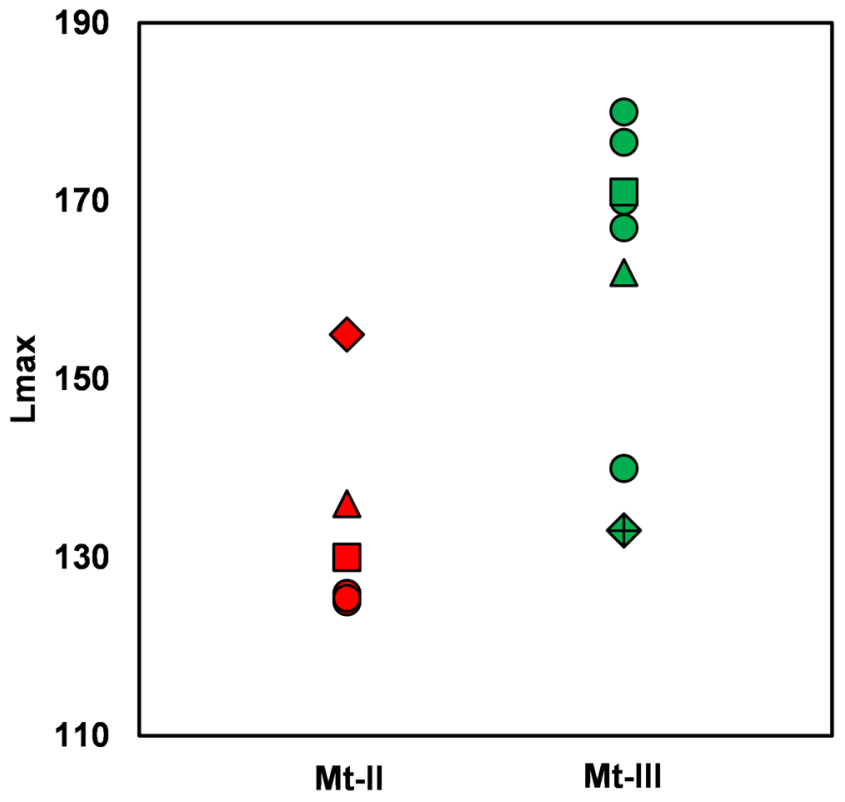

Fig. 4 Univariate plot of the maximal length (Lmax) of the $M t-I I$ (red) and Mt-III (green) of Ancylotherium pentelicum. The values are based on specimens from the following localities (Tables 2 and 3): Pikermi, Samos (Greece), Salihpaşalar, Pinaryaka, Kemiklitepe (Turkey), and "Titov Veles" (North Macedonia) (Roussiakis and Theodorou 2001; Saraç et al. 2002; Giaourtsakis and Koufos 2009). The red rhombus represents the Mt-II from Kerassia 4 (K4/119/7). The green rhombus with a cross represents the Mt-III from Kerassia 1 (K1/171). The red and green squares represent the presumably associated Mt-II and Mt-III from Pikermi (PIK 3540). The red and green triangles represent the associated Mt-II and Mt-III from Kiro Kuchuk (MMNH-Sk KK 2733)
Geraads et al. (2006) reported a notable morphological variability in the dental morphology of $A$. pentelicum from Bulgarian localities (Hadjidimovo and Kalimantsi). More specifically, the enamel folds in the teeth and the morphology of the cingula seem to vary significantly. In some specimens, a crochet and a crista can be present in the premolars, while other specimens lack these features; the shape and size of the P4 may also vary (Geraads et al. 2006).

On the proximal surface of the Mt-II, the shape of the articular facet for the mesocuneiform seems to be a variable feature within A. pentelicum. Saraç et al. (2002) described two specimens of Mt-II from the same locality (Pinaryaka, Turkey) with differently shaped articular facets for the mesocuneiform, one with a square outline (AAP-60) and the other one with a triangular outline (AAP-54). In K4/119/7, this articular facet is somewhat damaged, but was probably semi-ovate. The variable nature of this articular facet in chalicotheriines has also been discussed by Butler (1965) and Zapfe (1979). In addition, as discussed above, the presence of an articular facet for the cuboid on the Mt-III seems also to be variably expressed in some chalicotheres (Coombs 1979; Giaourtsakis and Koufos 2009). In the Mt-III from Kerassia (K1/171), a well-developed articular facet for the cuboid does exist, similar to one specimen from Pikermi (PG 95/551), whereas in another specimen from Pikermi (PG 95/515) and two specimens from Samos (MTLA-277 and MYT-64), this articular facet is potentially absent (Giaourtsakis and Koufos 2009). Another variable feature in the postcranium of $A$. pentelicum, 
Table 2 Measurements (in mm) of the Mt-II of Ancylotherium pentelicum (Gaudry and Lartet, 1856). Measurement abbreviations: 1, Lmax; 2, DTprox; 3, DAPprox; 4, DTdia; 5, DAPdia; 6, DTdistmax; 7, DTdist; 8, DAPdist

\begin{tabular}{|c|c|c|c|c|c|c|c|c|c|}
\hline Specimen No. & Reference & Locality & 1 & 2 & 3 & 4 & 5 & 7 & 8 \\
\hline $\mathrm{K} 4 / 119 / 7$ & This study & Kerassia 4 & 155 & $>53$ & 56.6 & 40.7 & 41 & 60.3 & 63 \\
\hline PG 95/552 (juvenile) & Roussiakis and Theodorou 2001 & Pikermi & 123.4 & 40.5 & 30.3 & 36.7 & 29.1 & - & 47.6 \\
\hline PIK3540c & Gaudry 1863 & Pikermi & 130 & 40 & 26 & 45 & - & 50 & - \\
\hline- & Zapfe 1979 & Pikermi & - & 53 & 44 & - & - & 57 & 52.5 \\
\hline AAP-54 & Sarac et al. 2002 & Pinaryaka & 126 & 53 & - & 37 & 30 & 42 & 60 \\
\hline AAP-60 & Sarac et al. 2002 & Pinaryaka & 129 & 46 & 52 & 41 & 43 & 52 & 59 \\
\hline MMNH-Sk KK 2733 & Spassov et al. 2018 & Kiro Kuchuk & 136 & - & - & - & - & - & - \\
\hline KTB-93 & Sen 1994 & Kemiklitepe & 125.4 & 49.4 & 48.3 & - & - & 54.2 & 64.7 \\
\hline MYS-1852 & Sarac et al. 2002 & Salihpaşalar & 125 & 48 & 38 & - & - & 40 & 52 \\
\hline
\end{tabular}

seems to be the morphology of the proximal articular facets of the Mc-IV (Saraç et al. 2002; Schaub 1943). Also, the astragalus seems to preserve some degree of variation in its morphology (Geraads et al. 2001; Sarac et al. 2002; Zapfe 1979). These dental and postcranial morphological differences, however, are most probably associated with an anticipated individual variability and not sexual dimorphism, because they occur within individuals from the same localities.

The specimens from Kerassia originate from two different sites. Two specimens (K1/80 and K1/171) originate from the upper horizon and belong to small individuals, whereas specimen K4/119/7 originates from the lower horizon and represents a morphometrically larger individual. A notable size variation in the metapodial elements of A. pentelicum can be also observed in other localities, such as Pikermi (Roussiakis and Theodorou 2001), Salihpaşalar (Saraç et al. 2002),
Akkașdağ1 (Saraç and Sen 2005), and Hadjidimovo (Geraads et al. 2006) (compare Fig. 4). The Mt-II (K4/119/ $7)$ and the Mt-III (K1/171) from Kerassia expand the size variability of the lengths of these metapodials (Fig. 4). However, a consistent linear trend of temporal or spatial decrease (or increase) in size cannot be observed within the known material of A. pentelicum from the Turolian localities of the Eastern Mediterranean. Therefore, the presumed small time interval between the two fossiliferous horizons of Kerassia (Iliopoulos 2003; Theodorou et al. 2003) may not indicate an evolutionary trend towards smaller size through time.

The intraspecific morphological and morphometrical variability observed in members of the family Chalicotheriidae has been previously discussed and evaluated. For instance, the well-sampled schizotheriine Moropus elatus from North America is known to display a significant sexual dimorphism

Table 3 Measurements (in mm) of the Mt-III of Ancylotherium pentelicum (Gaudry and Lartet, 1856). Measurement abbreviations: 1, Lmax; 2, DTprox; 3, DAPprox; 4, DTdia; 5, DAPdia; 6, DTdistmax; 7, DTdist; 8, DAPdist

\begin{tabular}{|c|c|c|c|c|c|c|c|c|}
\hline Specimen No. & Reference & Locality & 1 & 2 & 3 & 4 & 7 & 8 \\
\hline K1/171 & This study & Kerassia 1 & 133 & 54.5 & 45.5 & - & $\sim 47.7$ & - \\
\hline PG 95/513 & Roussiakis and Theodorou 2001 & Pikermi & 167 & 58.5 & 60.3 & 47.9 & 59.3 & 64.8 \\
\hline PG 95/515 & Roussiakis and Theodorou 2001 & Pikermi & 176.6 & 62.9 & 54.1 & 47.2 & - & 64.5 \\
\hline $\begin{array}{l}\text { PG 95/551 } \\
\text { (juvenile) }\end{array}$ & Roussiakis and Theodorou 2001 & Pikermi & - & 46.2 & 44.5 & 34.8 & - & - \\
\hline- & Zapfe 1979 & Pikermi & 140 & 48 & 45 & - & 47 & 57 \\
\hline PIK 3540d & Gaudry 1863 & Pikermi & 170 & 58 & 55 & 46 & 56 & - \\
\hline NHML M 9042 & Geraads pers. comm. & Pikermi & 180 & 64 & - & - & 64 & - \\
\hline MTLA-227 & Giaourtsakis and Koufos 2009 & Samos (MTLA) & - & 57.6 & 52.5 & 46.2 & - & - \\
\hline MYT-64 & Giaourtsakis and Koufos 2009 & Samos (MYT) & - & 60.7 & 53 & 48.8 & - & - \\
\hline MMNH-Sk KK 2733 & Spassov et al. 2018 & Kiro Kuchuk & 162 & - & - & 40 & 56 & - \\
\hline- & Schlosser 1921 & Veles & 170 & 60 & - & - & 59 & - \\
\hline MYS-757 & Sarac et al. 2002 & Salihpaşalar & 140 & 56 & 43 & 39 & 36 & 54 \\
\hline
\end{tabular}


(Coombs 1975). More specifically, based on the measurements provided by Coombs (1975, tab. 2), the greatest observed size difference in $M$. elatus is approximately $27.6 \%$ for the Mt-II $(N=7)$. In A. pentelicum, the respective size differences are comparable, with $24 \%$ for the Mt-II $(N=7)$ and $35.3 \%$ for the Mt-III $(N=9)$. The apparently smaller difference of $17.2 \%$ recorded for the Mt-III of M. elatus ( $N$ $=3$ ) may be affected by the smaller sample size.

In general, such degree of intraspecific size variation is frequently associated with sexual dimorphism (Mallon 2017). Regarding the two metatarsals under consideration, the available material of the schizotheriine A. pentelicum shows a similar absolute range of metrical variation as the schizotheriine M. elatus. However, the segregation of two different size groups is currently not as clear (Fig. 4). The associated Mt-II and Mt-III of the articulated partial pes (MMNH-Sk KK 2733), which was discovered in situ at the locality of Kiro Kuchuk (Spassov et al. 2018, pl. 6, fig. 5), as well as the presumably associated Mt-II and Mt-III from Pikermi (PIK 3540; Gaudry 1862-67, pl. 20, fig. 3), suggest that the boundaries between male and female specimens of A. pentelicum cannot be presently determined (Fig. 4). The notable size variation may thus be considered as indicative of sexual dimorphism, but a potential overlapping between male and female specimens may possibly occur. Another hypothesis would be the existence of a second Ancylotherium species in the Turolian of the Eastern Mediterranean, potentially with different metapodial proportions. Although, some dental features vary within A. pentelicum, no clear trend can be identified that would justify its split into different species or subspecies. Furthermore, if this dental variability was considered to have taxonomic importance, this would imply the existence of two Ancylotherium species in the same locality (e.g. Pikermi), which is very unlikely. Therefore, due to the lack of any significant craniodental and postcranial morphological features, this latter hypothesis cannot be presently supported. The attribution of these biometrical differences observed in the metapodials of A. pentelicum to sexual dimorphism, potentially with some overlapping between male and female individuals, seems thus to represent the most likely option, given the fact that similar dimorphism has been already established for several other chalicotheriine and schizotheriine taxa (Coombs 1975, 1979).

\section{Conclusions}

The occurrence of the schizotheriine chalicotheriid Ancylotherium pentelicum (Gaudry and Lartet, 1856) has been firmly recognised in both fossiliferous horizons of Kerassia, based on three metapodials. The morphometrical and morphological features observed in these specimens allow a discussion of the potential intraspecific variability observed in the known metapodials of A. pentelicum. This issue has been previously discussed, but without any decisive conclusions. The present comparison of several metapodial elements of A. pentelicum from different late Miocene localities of the Eastern Mediterranean supports the existence of a notable intraspecific variability, primarily in size. This size variability most probably represents a strong sexual dimorphism, which has been also observed in several other chalicotheriine and schizotheriine taxa.

Acknowledgements We would like to thank all the participants of the excavations in Kerassia. Furthermore, we would like to thank A. T. Matzke and F. J. Augustin for fruitful discussions. We thank the reviewers M. C. Coombs and D. Geraads for their helpful comments and suggestions, which significantly improved the manuscript.

Funding Open Access funding enabled and organized by Projekt DEAL. The excavations in Kerassia from 1992 to 2015, under the supervision of G. E. Theodorou, were funded by the local authorities, the General Secretariat for Research and Technologies of Greece, and NKUA Research Account projects 70/4/1394, 70/3/2842, 70/3/3922, 70/3/ 8567 , and $70 / 3 / 12301$.

Availability of data and material The specimens are housed in the collections of the Palaeontological and Geological Museum of the National and Kapodistrian University of Athens (Greece).

\section{Declarations}

Conflicts of interest The authors declare that they have no conflict of interest.

Open Access This article is licensed under a Creative Commons Attribution 4.0 International License, which permits use, sharing, adaptation, distribution and reproduction in any medium or format, as long as you give appropriate credit to the original author(s) and the source, provide a link to the Creative Commons licence, and indicate if changes were made. The images or other third party material in this article are included in the article's Creative Commons licence, unless indicated otherwise in a credit line to the material. If material is not included in the article's Creative Commons licence and your intended use is not permitted by statutory regulation or exceeds the permitted use, you will need to obtain permission directly from the copyright holder. To view a copy of this licence, visit http://creativecommons.org/licenses/by/4.0/.

\section{References}

Alberdi, M. T., López Martínez, N., Morales, J., Sesé, C., \& Soria, D. (1981). Bioestratigrafía y biogeografia de la fauna de mamíferos de Los Valles de Fuentidueña (Segovia). Estudios Geológicos, 37, 507-511.

Athanassiou, A., Roussiakis, S. J., Giaourtsakis, I. X., Theodorou, G. E., \& Iliopoulos, G. (2014). A new hornless rhinoceros of the genus Acerorhinus (Perissodactyla: Rhinocerotidae) from the Upper Miocene of Kerassiá (Euboea, Greece), with a revision of related forms. Palaeontographica Abteilung A, 303(1-3), 23-59. https:// doi.org/10.1127/pala/303/2014/23. 
Bernor, R. L. (1983). Geochronology and zoogeographic relationships of Miocene Hominoidea. In R. L. Ciochon \& R. S. Corruccini (Eds.), New Interpretations of Ape and Human Ancestry (pp. 21-64). Plenum Press.

Bonis, L. de, Bouvrain, G., Koufos, G., \& Tassy, P. (1995). Un crâne de chalicothére (Mammalia, Perissodactyla) du Miocène superieur de Macédoine (Grece): remarques sur la phylogenie des Chalicotheriinae. Palaeovertebrata, 24(1-2), 135-176.

Bonis, L. de, Brunet, M. de, Heintz, E., \& Sen, S. (1992). La province Greco-irano-afghane et la répartition des faunes mammaliennes au Miocène supérieur. Paleontologia i Evolucio, 24-25, 103-112.

Butler, P. M. (1965). Fossil mammals of Africa No. 18: East African Miocene and Pleistocene chalicotheres. Bulletin of the British Museum (Natural History) Geology, 10(7), 163-237.

Coombs, M. C. (2009). The chalicothere Metaschizotherium bavaricum (Perissodactyla, Chalicotheriidae, Schizotheriinae) from the Miocene (MN5) Lagerstätte of Sandelzhausen (Germany): description, comparison, and paleoecological significance. Paläontologische Zeitschrift, 83(1), 85-129. https://doi.org/10.1007/s12542-009-0004-x.

Coombs, M. C., \& Cote, S. M. (2010). Chalicotheriidae. In L. Werdelin (Ed.), Cenozoic Mammals of Africa (pp. 659-668). University of California Press. https://doi.org/10.1525/california/ 9780520257214.003.0033.

Coombs, M. C. (1975). Sexual dimorphism in chalicotheres (Mammalia, Perissodactyla). Systematic Zoology, 24(1), 55-62. https://doi.org/ $10.2307 / 2412697$.

Coombs, M. C. (1978). Reevaluation of the early Miocene North American Moropus (Perissodactyla, Chalicotheriidae, Schizotheriinae). Bulletin of Carnegie Museum of Natural History, 4, 1-62.

Coombs, M. C. (1979). Tylocephalonyx, a new genus of North American dome-skulled chalicotheres (Mammalia, Perissodactyla). Bulletin of the American Museum of Natural History, 164(1), 1-68.

Coombs, M. C. (1983). Large mammalian clawed herbivores: A comparative study. Transactions of the American Philosophical Society, 73(7), 1-96. https://doi.org/10.2307/3137420.

Cuvier, G. (1823). Sur une phalange ongueale fossile qui annonce a elle seule un Edente inconnu, probablement du genre des pangolins, et de taille giantesque. Recherches sur les Ossemens fossils, 5(1), 193195.

Fahlke, J. M., \& Coombs, M. C. (2009). Dentition and first postcranial description of Metaschizotherium fraasi Koenigswald, 1932 (Perissodactyla: Chalicotheriidae) and its occurrence on a karstic plateau - new insights into schizotheriine morphology, relationships, and ecology. Palaeontographica Abteilung A, 290(1-3), 65-129. https://doi.org/10.1127/pala/290/2009/65.

Gaudry, A. (1862-1867). Animaux fossiles et géologie de l'Attique. F. Savy (Ed.), (1-476 pp.) Paris.

Gaudry, A., \& Lartet, E. (1856). Sur les resultats des recherches paldontologiques entreprises dans l'Attique sou les auspices de l'Acaddmie. Comptes Rendus des Seances d l'Academie des Sciences, 43, 271-274.

Geraads, D. (2017). Late Miocene large mammals from Mahmutgazi, Denizli province, Western Turkey. Neues Jahrbuch für Geologie und Paläontologie - Abhandlungen, 284(3), 241-257.

Geraads, D., Spassov, N., \& Kovachev, D. (2001). New Chalicotheriidae (Perissodactyla, Mammalia) from the Late Miocene of Bulgaria. Journal of Vertebrate Paleontology, 21(3), 596-606. https://doi. org/10.1671/0272-4634(2001)021[0596:NCPMFT]2.0.CO;2.

Geraads, D., Spassov, N., \& Kovachev, D. (2006). The Bulgarian Chalicotheriidae (Mammalia): An update. Revenue de Paléobiologie, Genève, 25(2), 429-437.

Geraads, D., Tsoukala, E., \& Spassov, N. (2007). A skull of Ancylotherium (Chalicotheriidae, Mammalia) from the late Miocene of Thermopigi (Serres, N. Greece) and the relationships of the genus. Journal of Vertebrate Paleontology, 27(2), 461-466.
https://doi.org/10.1671/0272-4634(2007)27[461:ASOACM]2.0. $\mathrm{CO} ; 2$.

Giaourtsakis, I., Theodorou, G., Roussiakis, S., Athanassiou, A., \& Iliopoulos, G. (2006). Late Miocene horned rhinoceroses (Rhinocerotinae, Mammalia) from Kerassia (Euboea, Greece). Neues Jahrbuch für Geologie und Paläontologie - Abhandlungen, 239(3), 367-398.

Giaourtsakis, I. X., \& Koufos, G. D. (2009). The late Miocene mammal faunas of the Mytilinii Basin, Samos Island, Greece: New collection 10. Chalicotheriidae. Beiträge zur Paläontologie, 31, 189-205.

Gill, T. (1872). Arrangement of the families of mammals with analytical tables. Smithsonian Miscellaneous Collections, 11(1-5), 1-98.

Holland, W. J., \& Peterson, O. A. (1914). The osteology of the Chalicotheroidea with special reference to a mounted skeleton of Moropus elatus Marsh, now installed in the Carnegie Museum. Memoirs of the Carnegie Museum, 3, 189-406.

Iliopoulos, G. (2003). The Giraffidae (Mammalia, Artiodactyla) and the study of the histology and chemistry of fossil mammal bone from the late Miocene of Kerassia (Euboea Island, Greece), Ph.D. Dissertation. University of Leicester.

Kampouridis, P., \& Dimakopoulos, G. (2018). Taxonomic identification of the Turolian fauna of Kerassia, Euboea (Greece) (B.Sc. Thesis). National and Kapodistrian University of Athens.

Kampouridis, P., Roussiakis, S., Kargopoulos, N., Giaourtsakis, I., Dimakopoulos, G., Iliopoulos, G., Svorligkou, G., \& Theodorou, G. (2019). Faunal diversity at the Turolian locality of Kerassia (Northern Euboea, Greece). In Bulletin of the Geological Society of Greece, (Vol. Sp. Pub. 7, p. 2). Presented at the 15th International Congress of the Geological Society of Greece, Athens, Greece.

Kampouridis, P., Giaourtsakis, I., Roussiakis, S., Kargopoulos, N., Svorligkou, G., \& Theodorou, G. (2020a). New material of Ancylotherium pentelicum (Mammalia, Chalicotheriidae) at the Late Miocene locality of Kerassia (Euboea Island, Greece). In 2nd Palaeontological Virtual Congress Book of Abstracts, Presented at the 2nd Palaeontological Virtual Congress (p. 174) http://palaeovc.uv.es.

Kampouridis, P., Michailidis, D., Kargopoulos, N., Roussiakis, S., \& Theodorou, G. (2020b). First description of an ostrich from the late Miocene of Kerassia (Euboea, Greece): remarks on its cervical anatomy. Historical Biology, 1-8. https://doi.org/10.1080/08912963. 2020.1779252.

Kaup, J. (1833). Description d'ossements fossiles de Mammifères inconnus jusqu'à présent qui se trouvent au Muséum grand-ducal de Darmstadt (119 pp). J. G. Heyer.

Kaya, T., Geraads, D., \& Tuna, V. (2005). A new late Miocene mammalian fauna in the Karaburun Peninsula (W. Turkey). Neues Jahrbuch für Geologie und Paläontologie - Abhandlungen, 236(3), 321-349.

Koenigswald, G. H. R. v. (1932). Die Tertiären Wirbeltiere des Steinheimer Beckens: Metaschizotherium fraasi n. g. n. sp., ein neuer Chalicotheriide aus dem Obermiocän von Steinheim a. Albuch. Paleontographica Supplement, 8, 1-24.

Koufos, G. D. (2012). New material of Chalicotheriidae (Perissodactyla, Mammalia) from the Late Miocene of Axios Valley, Macedonia (Greece) with the description of a new species. Annales de Paleontologie, 98(3), 203-224. https://doi.org/10.1016/j.annpal. 2012.06.002.

Koufos, G. D., \& Kostopoulos, D. S. (2016). Chalicotheriidae. Geobios, 49(1-2), 75-83. https://doi.org/10.1016/j.geobios.2016.01.014.

Lartet, E. (1837). Sur les débris fossiles trouvés à Sansan et sur les animaux antédiluviens en général. Comptes Rendus des Seances d l'Academie des Sciences, 5, 1-158.

Linnaeus, C. (1758). Systema naturce per regna tria naturce, secundum classes, ordines, genera, species, cum characteribus, differentiis, synonymis, locis. Holmiae, Laurentii Salvii: Editio decima, reformata. 
Mallon, J. C. (2017). Recognizing sexual dimorphism in the fossil record: Lessons from nonavian dinosaurs. Paleobiology, 43(3), 495-507. https://doi.org/10.1017/pab.2016.51.

Mein, P., \& Ginsburg, L. (2002). Sur l'âge relatif des différents dépôts karstiques miocènes de La Grive-Saint-Alban (Isère). Cahiers scientifiques du Muséum d'histoire naturelle de Lyon - Centre de conservation et d'étude des collections, 5, 7-47.

Munthe, J., \& Coombs, M. C. (1979). Miocene dome-skulled chalicotheres (Mammalia, Perissodactyla) from the western United States: A preliminary discussion of a bizarre structure. Journal of Paleontology, 53(1), 77-91.

Owen, R. M. (1848). Description of teeth and proportion of jaws of two extinct Anthracotherioid quadrupeds (Hyopotamus vectianus and Hyopotamus bovinus) discovered by the marchioness of hastings in the Eocene deposits on the N.W. coast of the Isle of Wight: With an attempt to develop Cuvier's idea of the classification of pachyderms by the number of their toes. The Quaternary Journal of the Geological Society of London, 4, 103-141.

Roussiakis, S., Kargopoulos, N., Kampouridis, P., Svorligkou, G., \& Theodorou, G. (2021). The fossil aardvark Amphiorycteropus gaudryi (Forsyth Major, 1888) from the late Miocene of Kerassia (Euboea, Greece). Historical Biology, 1-14 https://doi.org/10.1080/ 08912963.2021 .1931167$.

Roussiakis, S., \& Theodorou, G. (2001). Ancylotherium pentelicum (Gaudry and Lartet, 1856) (Perissodactyla, Mammalia) from the classic locality of Pikermi (Attica, Greece), stored in the Palaeontological and Geological Museum of Athens. Geobios, 34(5), 563-584.

Roussiakis, S., \& Theodorou, G. (2003). Carnivora from the Late Miocene of Kerassia (Northern Euboea, Greece). Deinsea, 10, 469-497.

Saraç, G., Kaya, T., \& Geraads, D. (2002). Ancylotherium pentelicum (Perissodactyla, Mammalia) from the Upper Miocene of central and western Turkey. Geobios, 35, 241-251.

Saraç, G., \& Sen, S. (2005). Chalicotheriidae (Mammalia, Perissodactyla) from the late Miocene of Akkașdağı, Turkey. Geodiversitas, 27(4), 591-600.

Schaub, S. (1943). Die Vorderextremität von Ancylotherium pentelicum Gaudry and Lartet. Schweizerische Paläontologische Abhandlungen, $64,1-36$.
Schulz, E., \& Fahlke, J. M. (2009). The diet of Metaschizotherium bavaricum (Chalicotheriidae, Mammalia) from the MN 5 of Sandelzhausen (Germany) implied by the mesowear method. Paläontologische Zeitschrift, 83, 175-181. https://doi.org/10.1007/ s12542-009-0007-7.

Schulz, E., Fahlke, J. M., Merceron, G., \& Kaiser, T. M. (2007). Feeding ecology of the Chalicotheriidae (Mammalia, Perissodactyla, Ancylopoda). Results from dental micro- and mesowear analyses. Verhandlungen des Naturwissenschaftlichen Vereins Hamburg, 43, 5-31.

Semprebon, G. M., Sise, P. J., \& Coombs, M. C. (2011). Potential bark and fruit browsing as revealed by stereomicrowear analysis of the peculiar clawed herbivores known as chalicotheres (Perissodactyla, Chalicotherioidea). Journal of Mammalian Evolution, 18(1), 33-55. https://doi.org/10.1007/s10914-010-9149-3.

Sen, S. (1994). Les giesments de mammifères du Miocène supérieur de Kemiklitepe, Turquie: 5. Rongeurs, Tubulidentés et Chalicothères. Bulletin du Muséum d'histoire naturelle sér. C, 16(1), 94-111.

Spassov, N., Geraads, D., Hristova, L., Markov, G. N., Garevska, B., \& Garevski, R. (2018). The late Miocene mammal faunas of the Republic of Macedonia (FYROM). Palaeontographica Abteilung A, 311(1-6), 1-85. https://doi.org/10.1127/pala/2018/0073.

Spassov, N., Geraads, D., Hristova, L., \& Markov, G. N. (2019). The late Miocene mammal fauna from Gorna Sushitsa, southwestern Bulgaria, and the early/middle Turolian transition. Neues Jahrbuch für Geologie und Paläontologie - Abhandlungen, 291(3), 317-350.

Theodorou, G., Athanassiou, A., Roussiakis, S., \& Iliopoulos, G. (2003). Preliminary remarks on the Late Miocene herbivores of Kerassiá (Northern Euboea, Greece). Deinsea, 10, 519-530.

Wessel, P., Smith, W. H. F., Scharroo, R., Luis, J., \& Wobbe, F. (2013). Generic mapping tools: improved version released. EOS, 94, 409410.

Zapfe, H. (1979). Chalicotherium grande (Blainville) aus der miozänen Spaltenfüllung von Neudorf an der March (Devinska Nova Ves), Tschechoslowakei. Neue Denkschriften des Naturhistorischen Museums in Wien, 2, 1-282.

Publisher's note Springer Nature remains neutral with regard to jurisdictional claims in published maps and institutional affiliations. 